\title{
Proteomic Study of Ribosomal Proteins from Escherichia coli, Saccharomyces cerevisiae, Bos taurus, Gallus gallus, and Oncorhynchus tshawytscha: Application in a Teaching Laboratory Setting
}

\author{
Yoshihiro Miura ${ }^{\dagger \neq}$, Eric Yeager ${ }^{\ddagger}$,James A. MacKenzie ${ }^{\ddagger}$, Kestutis Bendinskas ${ }^{\dagger}$ \\ ${ }^{\dagger}$ Department of Chemistry and ${ }^{\ddagger}$ Department of Biological Sciences, SUNY Oswego \\ Students:miura@oswego.edu,eay26@cornell.edu \\ Mentors: james.mackenzie@oswego.edu,kestutis.bendinskas@oswego.edu
}

\begin{abstract}
Ribosomes are central to protein synthesis and our understanding of ribosomes has advanced antibiotics research. The proteomic study of ribosomes presented here utilizes a combination of differential centrifugation and matrix assisted laser desorption/ionization-time of flight mass spectrometry (MALDI-TOF MS) to analyze ribosomes from various species in a teaching laboratory setting. Five biologically varied species were used: Escherichia coli (bacteria), Saccharomyces cerevisiae (yeast), Bos taurus (cow), Gallus gallus (chicken), and Oncorhynchus tshawytscha (Chinook salmon). Samples were lysed, ribosomes were isolated via ultracentrifugation using a discontinuous sucrose gradient and the individual protein subunits were separated via sodium dodecyl sulfate polyacrylamide gel electrophoresis. Tryptic digest and MALDI-TOF MS were then conducted on fifteen bands excised from the gel, and the mass spectra of both the whole protein sample and peptides were analyzed. Five out of these fifteen bands were positively identified as various ribosomal proteins, with two uncertain identifications. Additionally, three of the five positively identified proteins that travelled the same distance on the gel were determined to be orthologous. Finally, a class of 14 Biochemistry II students utilized these protocols, identified three ribosomal proteins and provided their evaluations of the ultracentrifugation-proteomics teaching laboratory.
\end{abstract}

\section{KEYWORDS}

Proteomics, MALDI-TOF MS, ultracentrifugation, ribosomes, teaching laboratory

\section{INTRODUCTION}

Ribosomes use the ribonucleic acid sequence of mRNA to synthesize proteins. ${ }^{1}$ Understanding ribosome structure is indispensable in endeavors such as the development of new antibiotics. ${ }^{2}$ Technological advances in gel-electrophoresis in combination with mass spectrometry allow scientists to understand the individual protein components of the ribosome. Nguyen-Lefebvre et al. successfully purified, identified, and quantified ribosomal proteins from human, rat, and chicken samples using a combination of techniques including two-dimensional-polyacrylamide gel electrophoresis (2D-PAGE), ultracentrifugation, matrix assisted laser desorption/ionization-time of flight mass spectrometry (MALDI-TOF MS), and liquid chromatography tandem mass spectroscopy (LC-MS/MS). ${ }^{3}$ Marquez et al., in a similar study, positively identified 128 out of 130 ribosomal proteins from the Archaean P. aerophilum and S. acidocaldarius, again using 2D-PAGE, ultracentrifugation, MALDI-TOF and LC-MS/MS. ${ }^{4} \mathrm{Xu}$ et al. performed a proteomic study of soybean leaves and identified a variety of metabolic and ribosomal proteins using the same techniques and instrumentation. ${ }^{5}$

The goal of this study was to successfully identify ribosomal proteins found in Escherichia coli, yeast, and in liver of cow, chicken, and salmon using a combination of ultracentrifugation and 
MALDI-TOF MS in a teaching laboratory setting. These five organisms were chosen for their availability and evolutionary variance. Past studies varied in the organisms and tissues from which ribosomes have been isolated. Some publications involved the extraction of bovine hepatic ribosomal proteins. ${ }^{6}$ Orvos et al. conducted a study to determine a protocol that would yield an optimal amount of salmon hepatic ribosomes. ${ }^{7}$ Nguyen-Lefebvre et al. successfully used this contemporary method to extract chicken ribosomes, but the study did not use liver. ${ }^{3}$ This study attempted to establish a unified procedure that would be compatible for extracting and analyzing cytosolic ribosomes from all five organisms in a teaching laboratory setting.

\section{PROCEDURE}

While it would have been convenient to homogenize each sample with the same procedure, the intrinsic differences between E. coli, yeast, and the liver samples required three different lysis protocols.

For E.coli, $1 \mathrm{~g}$ of sample was dissolved in $3 \mathrm{~mL}$ of solution A $(25 \mathrm{mM}$ Tris- $\mathrm{HCl}, 50 \mathrm{mM} \mathrm{KCl}$, $5 \mathrm{mM} \mathrm{MgSO}_{4}, 0.1 \mathrm{mM}$ EDTA, $7 \mathrm{mM}$ beta-mercaptoethanol, $250 \mathrm{mM}$ sucrose, $\mathrm{pH}$ 7.6) in a $15 \mathrm{~mL}$ centrifuge tube (reagents and supplies are from Thermo Scientific, Waltham, MA, unless otherwise specified). This solution was then sonicated using a Branson sonifier (Model 450, Branson Ultrasonics, VWR, Danbury, CT) for two minutes at setting 3 on a $30 \%$ cycle while on ice. This process causes localized low pressure regions that result in acoustic cavitation, ultimately lysing the cell.

For yeast, $1 \mathrm{~g}$ of sample was dissolved in $3 \mathrm{~mL}$ of solution $\mathrm{A}$, and homogenized with a French press (Sim-Aminco Spectronic Instruments, Rochester, NY) twice into a similar centrifuge tube. This device uses massive pressure to force the cells through a small opening, causing them to explode from the pressure gradient as they exit the press.

For the liver samples, a mortar and pestle were used to grind the samples with $4.5 \mathrm{~mL}$ of solution A and 0.5 grams of sea sand. The liver homogenate was then filtered through 8 layers of cheese cloth into a tube to remove crude cellular debris.

All five homogenates were then centrifuged for ten minutes at $4^{\circ} \mathrm{C}, 29,000 \mathrm{xg}$ in a centrifuge (RC6, Sorvall, Thermo Scientific) to pellet unlysed cells and cellular debris. The ribosome-containing supernatant was removed and centrifuged second time. The liver samples tended to accumulate a thin, undesirable layer of fat at the top of the tube which was removed with a pipette. Once the second round of centrifugation was complete, discontinuous sucrose gradients were prepared in 10 $\mathrm{mL}$ ultracentrifuge tubes: $2 \mathrm{~mL}$ of solution $\mathrm{C}$ (same composition as solution A but $2.0 \mathrm{M}$ sucrose) at the bottom of a tube, $2 \mathrm{~mL}$ of solution B (same as A but $1.5 \mathrm{M}$ sucrose), then $2.5 \mathrm{~mL}$ of supernatant from the homogenate on the top of a tube. The delineations of these layers can clearly be seen in Figure 1. The tubes were then placed in a T-890 fixed angle rotor, and spun in an ultracentrifuge (WX80, Sorvall, Thermo Scientific) at $180,000 \mathrm{xg}$ for 4 hours at $4^{\circ} \mathrm{C}$. 


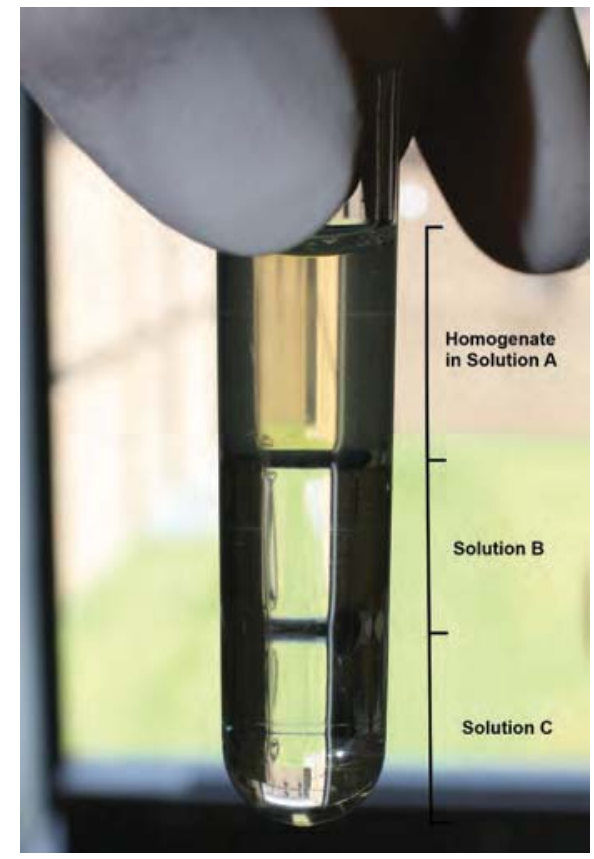

Figure 1. There is a clear delineation between the different layers of sucrose concentrations.

The supernatant was removed and pellets were resuspended in $100 \mu \mathrm{L}$ of water. UV-Vis spectrometry (Model 2000, NanoDrop, Thermo Scientific) was performed to confirm the presence of ribosomes in the samples. The expected A260/A280 absorbance ratio is approximately 1.8 to 1.9; protein concentration $(\mathrm{mg} / \mathrm{mL})=(1.55 \times \mathrm{A} 280)-(0.76 \times \mathrm{A} 260)$ (Equation 1$){ }^{8,9}$ This concentration is important to know so that the SDS-gel is not overloaded in the following step.

At this point in the study, the resuspended pellet contains at least 50 different proteins. Therefore, the protein mixture was separated using SDS-PAGE. Since we could not achieve good separation on a typical 2D gel due to the basic nature of ribosomal proteins, a premade $4-20 \%$ Tris- $\mathrm{HCl} 1 \mathrm{D}$ gradient gel (Criterion, BioRad, Hercules, CA) was used. The samples were first prepared in 2X SDS sample buffer (62.5 mM Tris-HCl, 69.4 mM SDS, $0.1 \mathrm{mM}$ bromophenol blue, $70 \mathrm{mM}$ beta-mercaptoethanol, $20 \% \mathrm{v} / \mathrm{v}$ glycerol) and then heated at $95^{\circ} \mathrm{C}$ for three minutes. Denatured proteins $(20 \mu \mathrm{g})$ from each sample were loaded along with several lanes of molecular weight markers. The gel was run at $200 \mathrm{~V}$ for one hour, washed twice for five minutes with water to remove excess SDS, and then stained with Bio-safe Coomassie (BioRad) to visualize the bands. Excess Coomassie dye was then removed from the background by washing the gel twice with water for five minutes.

Three bands from each sample lane were excised from the gel for further analysis. When selecting which bands to excise from the gel, we chose a band that seemed common among all of the species. Other bands were chosen based on how well they were separated from other bands so as to not mix proteins from other bands during excision. The excised gel pieces were placed in $1.6 \mathrm{~mL}$ protein-low-bind tubes (Eppendorf, Hamburg, Germany) with $200 \mu \mathrm{L}$ of destaining solution $\left(0.2 \%\right.$ ammonium bicarbonate in $50 \%$ acetonitrile) and incubated at $40^{\circ} \mathrm{C}$ for ten minutes to remove the Coomassie stain from protein bands. This step was repeated using fresh destaining solution until no dye remained visible. Stain removal is an essential step for successful digestion because Coomassie binds to lysine and arginine amino acid residues - the same residues at which the digestive enzyme trypsin cuts later in the procedure.

Forty $\mu \mathrm{L}$ of reducing buffer $(100 \mathrm{mM}$ dithiothreitol) was then added to the sample and incubated at $60^{\circ} \mathrm{C}$ for ten minutes to sever the disulfide bridges between cysteine residues. After cooling, 
the solution was removed and $40 \mu \mathrm{L}$ of alkylating buffer (100 mM iodoacetamide) was added and stored in the dark at room temperature for an hour. This step served to "cap" the now broken disulfide bridges with amide groups, preventing the bridges from reforming. Two hundred $\mu \mathrm{L}$ of additional destaining buffer was added and incubated at $37^{\circ} \mathrm{C}$ for 15 minutes to remove any remaining reducing or alkylating agents. The solution was removed, and $50 \mu \mathrm{L}$ of acetonitrile was added which dehydrated and shrank the gel pieces. The acetonitrile was removed, and the pieces were air-dried for ten minutes, and then $15 \mu \mathrm{L}$ of activated trypsin (Modified Porcine Gold, Promega, Madison, WI) was added. This caused the gel to rehydrate and swell, drawing the trypsin into the gel. After incubating for 15 minutes at room temperature, $25 \mu \mathrm{L}$ of digestion buffer $(0.4 \%$ ammonium bicarbonate) was added and the tubes were incubated at $37^{\circ} \mathrm{C}$ with gentle shaking overnight. This final step allowed the trypsin enzyme to cut the proteins at lysine and arginine to yield a mixture of peptides, which were now small enough to freely diffuse out of the gel.

Next, the tubes were placed in a water bath sonicator (FS20, Fisher Scientific, Pittsburg, PA) for 30 minutes to help peptides diffuse out of the gel and remove any peptides that may have bound to the tube walls. The peptide solutions, after being transferred to new tubes, were then vacuum-centrifuged to dryness at $60^{\circ} \mathrm{C}$ for an hour. The samples were then resuspended in $10 \mu \mathrm{L}$ of Solution 1 ( $0.1 \%$ trifluoroacetic acid) and water-bath sonicated again for 30 minutes to redissolve all the peptides. In the final preparatory step before MALDI-TOF, the peptides were concentrated and purified using C4 Zip-tips (Millipore, Billerica, MA). These specialized pipette tips contain a non-polar resin that binds peptides and facilitates the removal of salts and other impurities. The tips were prepared by aspirating $10 \mu \mathrm{L}$ of Solution $2(50 \%$ acetonitrile and $50 \% 0.1 \%$ trifluoroacetic acid) twice, then $10 \mu \mathrm{L}$ of Solution 1 twice. Subsequently, each sample, with their own Zip-tips, were aspirated and dispensed seven times. The peptides, along with some impurities, were now bound to the resin in the tip, leaving salts behind in solution. By aspirating Solution 1, any impurities that may have also bound to the resin were discarded while the peptides were still bound. Finally, the tip was aspirated and dispensed three times into a new tube containing only $4 \mu \mathrm{L}$ of Solution 2 , removing the peptides from the resin, and concentrating them in an extremely small volume. The isolated peptides were now ready for analysis by mass spectroscopy using MALDI-TOF (Autoflex II, Bruker Daltonics GmbH, Billerica, MA).

MALDI-TOF is a technique which measures the mass/charge ratio of a variety of different biomolecules. For whole, undigested proteins, samples must be prepared in a 1:4 ratio of sample to $1 \%$ sinapinic acid (Fluka Analytical, Sigma-Aldrich, St. Louis, MO) matrix solution, whereas digested peptides must be prepared in a 1:4 ratio of sample to $1 \%$ a-hydroxycinnamic acid (Fluka Analytical) matrix solution. Both the total protein sample (unfractionated by gel electrophoresis) and the individually digested bands from the SDS-PAGE were analyzed on the MALDI-TOF. Two $\mu \mathrm{L}$ of each sample/matrix mixture were spotted onto the MALDI target plate along with protein and peptide standards to properly calibrate the instrument, then air dried. The MALDI-TOF utilizes a laser fired at the samples under a vacuum causing the matrix to absorb much of the laser's energy ionizing the sample. The matrix also gives all of these proteins/peptides predominantly +1 charge, and they travel through the vacuum due to a high voltage within the instrument, size differences being resolved by the time of flight. It is typical when using MALDI-TOF to vary the power of the laser and the number and location of shots - these parameters must be adjusted by the user during each analysis. 


\section{RESULTS}

Purified ribosomes were analyzed via UV-Vis spectroscopy of the dissolved pellets from the ultracentrifugation step (Table 1). Liver samples required a 100-fold dilution and the E.coli and yeast a 20 -fold dilution before analysis. All samples had an A260/A280 of approximately 2.0 and yielded a protein content between $9-10 \mu \mathrm{g} / \mathrm{mL}$, except for the salmon liver, which was $2 \mu \mathrm{g} / \mathrm{mL}$.

\begin{tabular}{|c|c|c|c|c|}
\hline Sample & Dilution & A260/A280 & A280 & $\begin{array}{c}\text { Protein } \\
\text { Concentration } \\
(\boldsymbol{\mu g} / \mathbf{m L})\end{array}$ \\
\hline Beef & 100 & 1.96 & 0.15 & 9 \\
\hline Chicken & 100 & 1.99 & 0.26 & 10 \\
\hline Salmon & 100 & 2.02 & 0.16 & 2 \\
\hline E.coli & 20 & 1.96 & 0.15 & 9 \\
\hline Yeast & 20 & 1.99 & 0.26 & 10 \\
\hline
\end{tabular}

Table 1. Absorbance Data Retrieved from UV-Vis Spectroscopy.

A representative gel of proteins from the pellets is shown in Figure 2, with the bands that were excised for protein identification being denoted by the boxes.

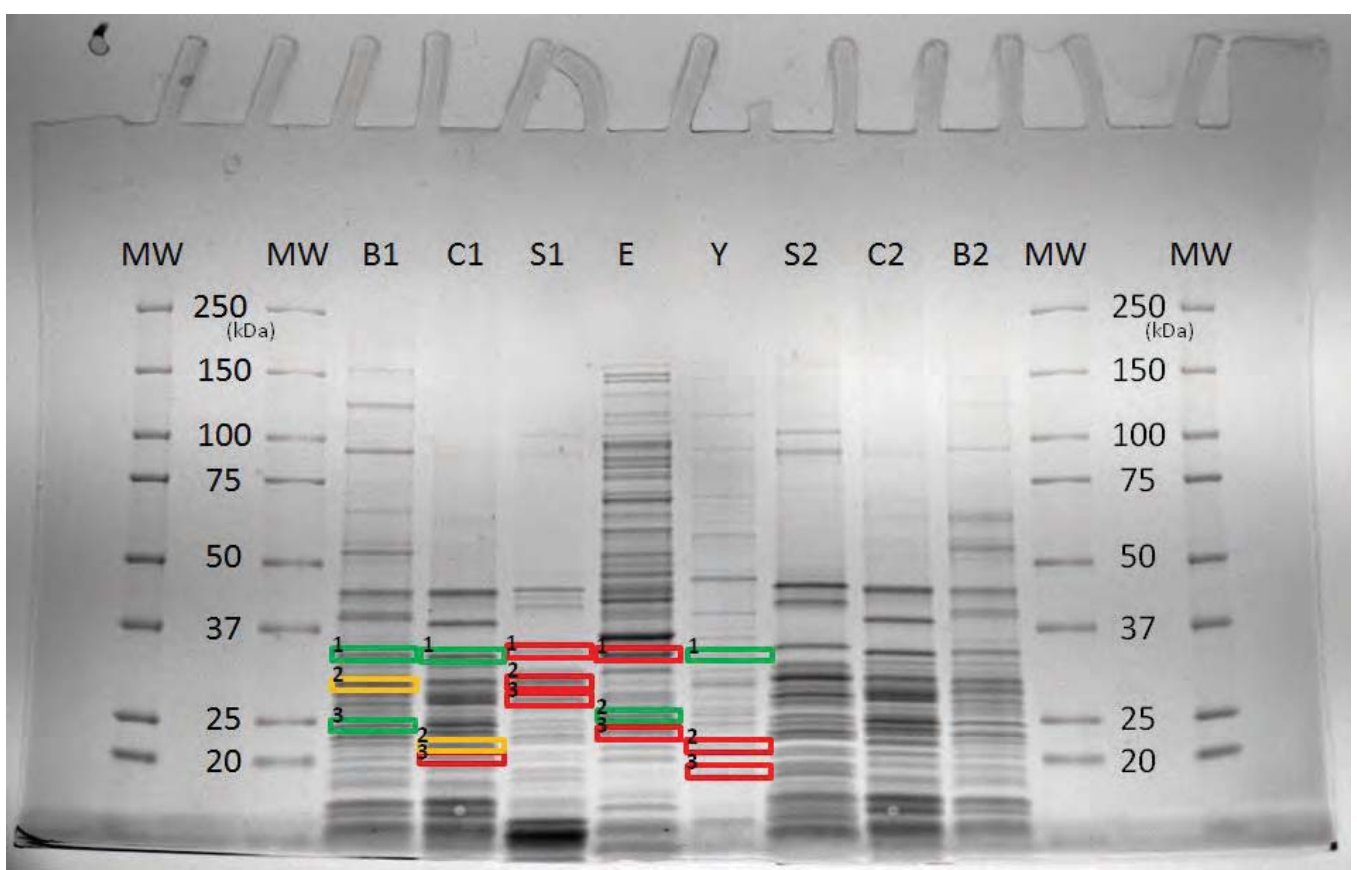

Figure 2. Molecular weight markers (MW) were separated via 4-20\% SDS-PAGE along with ribosomal proteins isolated from beef $(\mathrm{B} 1, \mathrm{~B} 2)$, chicken $(\mathrm{C} 1, \mathrm{C} 2)$, salmon $(\mathrm{S} 1, \mathrm{~S} 2)$, E. coli $(\mathrm{E})$, and yeast $(\mathrm{Y})$. The rectangles indicate which bands were excised and analyzed via tryptic digest and MALDI-TOF. The green rectangles were successfully identified with 95\% confidence, the orange rectangles have questionable results, and the red rectangles were not successfully identified. The smaller numbers next to the rectangles indicate the band's assigned number for easier reference. 
Figure 3 depicts the total protein spectra collected for each sample individually as well as a combined overlay. For the digested proteins in individual bands from the gel, the resulting peptide spectra were submitted to an online database (Swiss-Prot) for identification.
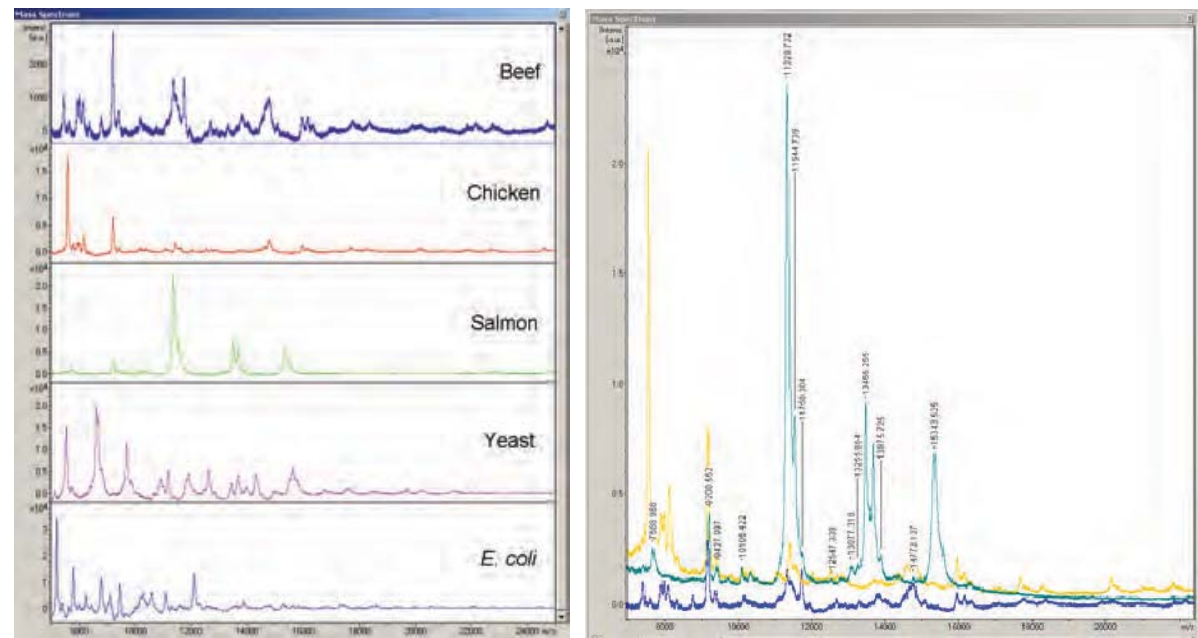

Figure 3. The total protein mass spectra for each organism, displayed side by side (left panel). The total protein displayed in an overlay manner: beef $=$ dark blue, chicken $=$ yellow, salmon $=$ aquamarine (right panel). $\mathrm{X}$ axis is the measured mass to charge ratio for proteins and y axis is intensity, which represents abundance of proteins. 
Figure 4 shows an example digest spectrum from a single band. Certain parameters of the database search were adjusted such as the taxonomy (the biological classification of the organism from which the sample was prepared), the peptide tolerance (a measure of the accuracy of the peak measurements) and the number of missing trypsin cleavages (the value of zero assumes that all cuts were perfectly complete, while 1 assumes that an occasionally cut was missed). The statistical significance of the search results were determined by the MOlecular Weight SEarch (MOWSE) score - the higher the value, the more significant the result. MOWSE score depends on the selected significance, the closeness of the hit, the size of the data base, etc. Figure 4 also shows the alignment of the spectra with the sequence of the protein. In that particular example, $68 \%$ intensity coverage and $45.1 \%$ sequence coverage were achieved and eighteen peaks were matched. The MOWSE score of 84 was achieved while the $95 \%$ significance for that set of search parameters was calculated to be at the MOWSE score of 70. A positive hit in a database provides detailed information about each protein, such as its isoelectric focusing point, molecular weight, amino acid sequence, number of possible peaks and the percent sequence coverage by this particular digest.

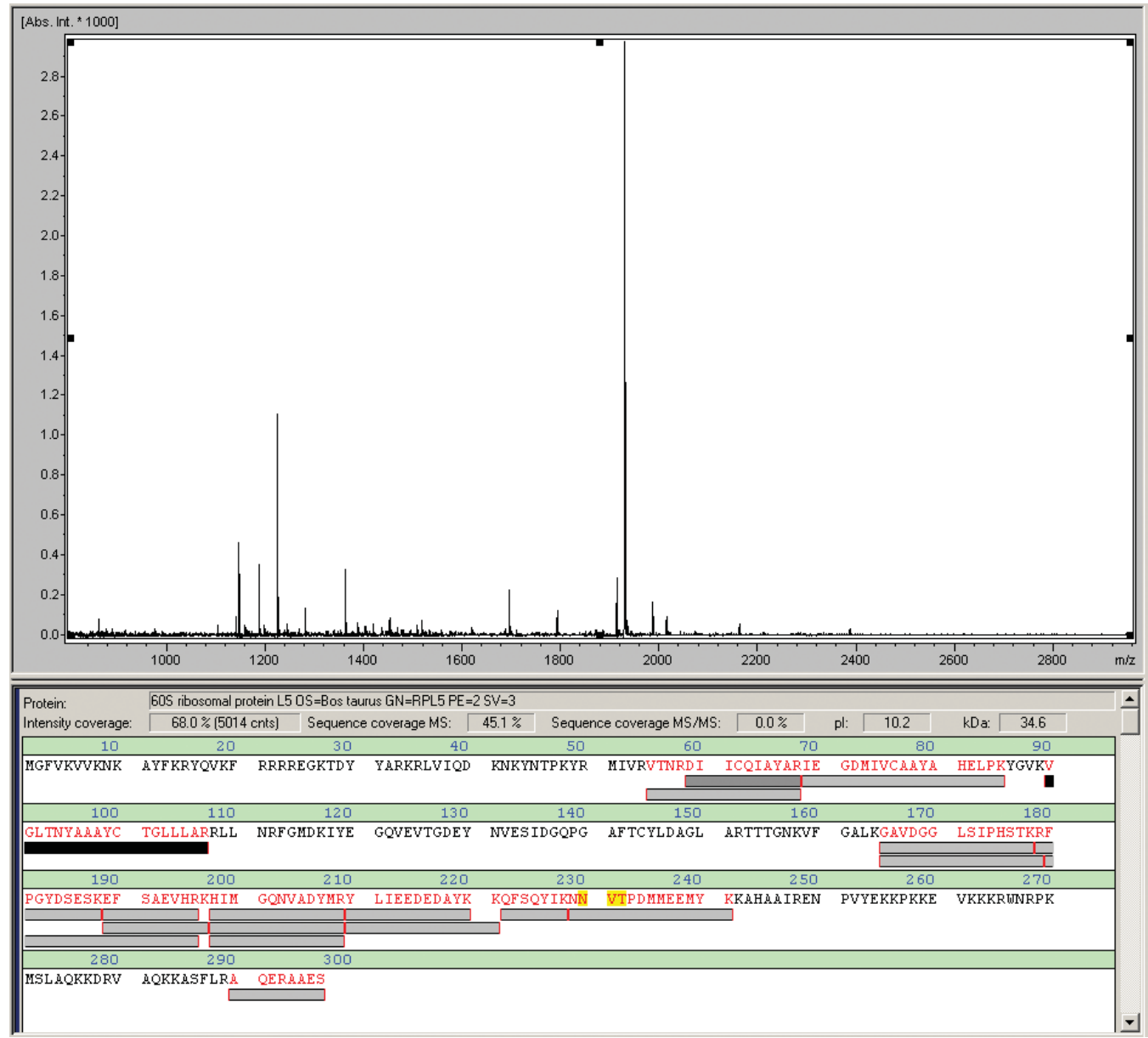

Figure 4. A representative image of the MALDI-TOF digest spectra (top section) and sequence alignment (bottom section) for beef band 1 . Eighteen peaks matched, and $68 \%$ intensity coverage and $45.1 \%$ sequence coverage were achieved. The protein was identified to be 60S Ribosomal Protein L5 (Bos taurus) and achieved the highest MOWSE score among all identified samples with a value of 84 . $\mathrm{X}$ axis is the measured mass to charge ratio for peptides and $\mathrm{y}$ axis is intensity, which represents the abundance of peptides. 
Table 2 summarizes the parameters used and the significant results collected from the database searches. A total of five different ribosomal proteins were identified, including three from beef liver (60S proteins L5 and L15, 40S protein S3), two from chicken liver (60S protein L5, 40S protein S9), one from E. coli (30S protein S4), and one from yeast (60S protein L5). We were not able to significantly identify any of the three bands from Figure 2 for salmon liver.

\begin{tabular}{|c|c|c|c|c|c|c|c|}
\hline $\begin{array}{c}\text { Band } \\
\text { Excised } \\
\text { from Fig } 2\end{array}$ & $\begin{array}{l}\text { Taxonomy } \\
\text { used in } \\
\text { search }\end{array}$ & $\begin{array}{l}\text { Peptide } \\
\text { Tolerance }\end{array}$ & Cleavages & Protein & $\begin{array}{l}\text { MOWSE } \\
\text { Score }\end{array}$ & $\begin{array}{c}\text { Mass of } \\
\text { Protein } \\
(\mathrm{kDa})\end{array}$ & $\begin{array}{c}\text { Approximate } \\
\text { MW Deduced } \\
\text { by PAGE } \\
\text { Markers (kDa) }\end{array}$ \\
\hline \multirow[t]{2}{*}{ Beef 1} & \multirow[t]{2}{*}{ All Entries } & \multirow[t]{2}{*}{0.8308} & \multirow[t]{2}{*}{1} & $\begin{array}{l}60 \text { S Ribosomal } \\
\text { Protein L5 }\end{array}$ & \multirow[t]{2}{*}{84} & \multirow[t]{2}{*}{34.551} & \multirow[t]{2}{*}{$34-35$} \\
\hline & & & & (Bos taurus) & & & \\
\hline \multirow[t]{2}{*}{ Beef 2} & \multirow[t]{2}{*}{$\begin{array}{c}\text { Other } \\
\text { Mammalian }\end{array}$} & \multirow[t]{2}{*}{0.4742} & \multirow[t]{2}{*}{1} & $\begin{array}{c}40 \text { S Ribosomal } \\
\text { Protein S3 }\end{array}$ & \multirow[t]{2}{*}{69} & \multirow[t]{2}{*}{26.984} & \multirow[t]{2}{*}{$30-32^{*}$} \\
\hline & & & & (Bos taurus) & & & \\
\hline \multirow[t]{2}{*}{ Beef 3} & \multirow[t]{2}{*}{$\begin{array}{c}\text { Other } \\
\text { Mammalian }\end{array}$} & \multirow[t]{2}{*}{0.3745} & \multirow[t]{2}{*}{1} & \begin{tabular}{|c|} 
60S Ribosomal \\
Protein L15 \\
\end{tabular} & \multirow[t]{2}{*}{57} & \multirow[t]{2}{*}{24.245} & \multirow[t]{2}{*}{$24-25$} \\
\hline & & & & (Bos taurus) & & & \\
\hline \multirow[t]{2}{*}{ Chicken 1} & \multirow[t]{2}{*}{ All Entries } & \multirow[t]{2}{*}{0.87} & \multirow[t]{2}{*}{2} & $\begin{array}{l}60 \text { S Ribosomal } \\
\text { Protein L5 }\end{array}$ & \multirow[t]{2}{*}{75} & \multirow[t]{2}{*}{34.298} & \multirow[t]{2}{*}{$34-35$} \\
\hline & & & & (Gallus gallus) & & & \\
\hline \multirow[t]{2}{*}{ Chicken 2} & \multirow[t]{2}{*}{$\begin{array}{c}\text { Bony } \\
\text { Vertebrates }\end{array}$} & \multirow[t]{2}{*}{0.4774} & \multirow[t]{2}{*}{0} & \begin{tabular}{|c|}
40 S Ribosomal \\
Protein S9 \\
\end{tabular} & \multirow[t]{2}{*}{$45 \dagger$} & \multirow[t]{2}{*}{22.635} & \multirow[t]{2}{*}{$22-23$} \\
\hline & & & & (Gallus gallus) & & & \\
\hline \multirow[t]{2}{*}{ E. coli 2} & \multirow[t]{2}{*}{ E. coli } & \multirow[t]{2}{*}{0.9937} & 1 & \begin{tabular}{|c|}
30 S Ribosomal \\
Protein S4 \\
\end{tabular} & 62 & 23.512 & $25-26$ \\
\hline & & & & (E.coli) & & & \\
\hline Yeast 1 & Yeast & 0.7023 & 2 & \begin{tabular}{|c|}
60 S Ribosomal \\
Protein L5 \\
\end{tabular} & 63 & 33.751 & $34-35$ \\
\hline & & & & (S. cerevisiae) & & & \\
\hline
\end{tabular}

Table 2. Significant Hits Collected from SwissProt Database. 
For each step outlined previously, a multitude of conditions were screened to find the optimum search parameters. All experiments were completed in triplicate. After the protocols were worked out, Biochemistry Laboratory II students ran the experiment in the Spring semester of 2012. These 14 students successfully identified 3 ribosomal proteins and provided feedback summarized in Table 3.

\begin{tabular}{|l|c|c|}
\hline Evaluation Questions & Average & SD \\
\hline $\begin{array}{l}\text { As a consequence of performing this laboratory experiment, how well do you under- } \\
\text { stand the difference between the "reductionist approach" to biology as opposed to } \\
\text { "systems" biology (e.g. protein vs proteomics)? }\end{array}$ & 3.8 & 0.7 \\
\hline How well do you understand the principles of proteomics? & 4.1 & 0.6 \\
\hline How well do you understand the concept of ultracentrifugation? & 4.7 & 0.5 \\
\hline $\begin{array}{l}\text { How well do you understand the processes of protein separation and modification } \\
\text { (prior to their analysis)? }\end{array}$ & 4.3 & 0.6 \\
\hline How well do you understand the principles of MALDI-TOF spectroscopy? & 4.3 & 0.9 \\
\hline How well do you understand the concept of protein mass fingerprinting? & 3.8 & 0.7 \\
\hline $\begin{array}{l}\text { How well do you understand the parameters involved in performing protein database } \\
\text { searches? }\end{array}$ & 3.5 & 1.1 \\
\hline Were the laboratory directions presented in a clear manner? & 4.4 & 0.6 \\
\hline Did you find this laboratory more interesting than a typical laboratory experiment? & 4.1 & 0.9 \\
\hline Would you recommend continuing this laboratory as part of this course in the future? & 4.5 & 0.9 \\
\hline Possible Answers & & \\
\hline (Not clear) 1 2 3 4 (Very clear) & & \\
\hline (Less interesting) 1 2 3 5 (More interesting) & & \\
\hline (Not inclined to recommend) 1 2 3 5 (Strongly inclined to recommend) & & \\
\hline Student-Identified Proteins & & \\
\hline Yeast 60S Ribosomal Protein (2X) & & \\
\hline Yeast 40S Ribosomal Protein & & \\
\hline E.coli 30S Ribosomal Protein & & \\
\hline
\end{tabular}

Table 3. Student results and evaluations of the ultracentrifugation-proteomics laboratory.

\section{DISCUSSION}

Our data in Table 1 indicates that we successfully purified ribosomes. The typical A260/A280 ratio, which was about 2.0, suggests the presence of ribonuclear proteins in the precipitated pellet. The downstream analysis via SDS-PAGE (Figure 2) and MALDI (Table 2, Figure 4) confirm the presence of ribosomal proteins. The yield of salmon ribosomal proteins was lower than in other species. When comparing the total protein spectra (Figure 3), it can be seen that even though the spectra are not identical, there are some similarities between them, particularly among the eukaryotes. Comparison between samples should be based on the presence or absence of peaks at particular mass/charge ratios, and not their intensities. Intensity is defined by the amount of protein present and the number of shots collected.

The similarities are strongest between the beef and chicken, but fish share some peaks with them as well. This is likely due to the evolutionary relationships between the three organisms-while they may be different species, they are all animals that belong to the phylum Chordata and on a cellular level they have many comparable characteristics. The fact that all living organisms require ribosomes to produce proteins would make these structures well-conserved among organisms, 
especially those which are evolutionarily close to each other. The peak similarity was not observed when comparing these three eukaryotes to another eukaryote, yeast. These differences are not surprising because yeast is a much simpler eukaryote-a single-celled organism of the kingdom Fungi. The similarities are also absent when comparing yeast to single-celled bacteria E. coli. This difference is likely attributed to the evolutionary divide between eukaryotes and prokaryotes which is highlighted by the different sizes of the overall ribosome for each group. ${ }^{1}$

After searching through the Swiss-Prot database, six statistically significant hits with a 95\% confidence interval were found (Figure 4, Table 2). Unfortunately, none of the bands excised from salmon produced significant hits, but conversely all three bands from beef yielded positive results. Upon closer inspection of the data, the result for Band 2 in beef may not have been a logical find. The database identified Band 2 as the 40S Ribosomal Protein S3, with a mass of approximately $27 \mathrm{kDa}$. When the location of the band is inspected on the SDS gel using the molecular weight markers as a reference, the band falls at about $32-34 \mathrm{kDa}$, which could be due to post-translational modifications. In this case, it is difficult to determine whether this band is truly the $40 \mathrm{~S}$ Ribosomal Protein S3. An additional LC-MS/MS study can be performed to determine whether this match is a false positive or not.

Out of the three chicken bands, only Band 1 was positively identified as a ribosomal protein. However, it is worth mentioning that Band 2 was rather close to being a significant hit. MOWSE scores can sometimes be improved by imposing stricter search parameters in peptide tolerance, but these efforts were insufficient to obtain a positive match with $95 \%$ confidence. The mass of $40 \mathrm{~S}$ Ribosomal Protein S9 does fall within the expected protein mass range from the gel, so there is a possibility that this band is in fact this protein. However, without more information to submit to the database, this cannot be confirmed.

One final compelling point of interest was that the significant results seen in Band 1 for beef, chicken and yeast were all identified as 60S Ribosomal Protein L5. The fact that these individually processed protein bands that travelled the same distance on the gel yielded the same exact ribosomal protein from different species is a powerful indicator that speaks to the validity of this experiment. Thus, we concluded that it was possible to successfully extract and identify ribosomal proteins from various species using ultracentrifugation and MALDI-TOF.

Finally, we replicated these methods in a Biochemistry II teaching laboratory. To the best of our knowledge the current literature lacks the description of a teaching laboratory that applies ultracentrifugation. This enables institutions with such instrumentation to try this experiment. The student and instructor's manuals are available from the corresponding author. As can be seen by student evaluations (Table 3), the experiment was well liked by students with the average valuation for all questions asked being 4.1 out of 5 . Future work in this study will include identification of all bands by LC-MS/MS with the help of our collaborators, repeating analysis of the bands via MALDI-TOF and the improvement of student protocols to ensure better identification rate and reproducibility.

\section{ACKNOWLEDGEMENTS}

We thank SUNY Oswego, specifically the Scholarly and Creative Activity Committee as well as the Provost's office for their support. We thank NSF-MRI for funds for the acquisition of an ultracentrifuge for undergraduate research training and teaching.

\section{SUPPLEMENTAL INFORMATION}

Supplemental material may be found online in PDF format alongside the associated article at www.ajuronline.org. 


\section{REFERENCES}

[1] Alberts, B., Wilson, J. H., and Hunt, T. (2008) Molecular biology of the cell, 5th ed., Garland Science, New York.

[2] Bulkley, D., Johnson, F., and Steitz, T. A. (2012) The antibiotic thermorubin inhibits protein synthesis by binding to inter-subunit bridge B2a of the ribosome, J Mol Biol 416, 571-578.

[3] Nguyen-Lefebvre, A. T., Gonin-Giraud, S., Scherl, A., Arboit, P., Granger, L., Sanchez, J. C., Diaz, J. J., Gandrillon, O., and Madjar, J. J. (2011) Identification of human, rat and chicken ribosomal proteins by a combination of two-dimensional polyacrylamide gel electrophoresis and mass spectrometry, Journal of proteomics $74,167-185$.

[4] Marquez, V., Frohlich, T., Armache, J. P., Sohmen, D., Donhofer, A., Mikolajka, A., Berninghausen, O., Thomm, M., Beckmann, R., Arnold, G. J., and Wilson, D. N. (2011) Proteomic characterization of archaeal ribosomes reveals the presence of novel archaeal-specific ribosomal proteins, J Mol Biol 405, $1215-1232$

[5] Xu, C., Garrett, W. M., Sullivan, J., Caperna, T. J., and Natarajan, S. (2006) Separation and identification of soybean leaf proteins by two-dimensional gel electrophoresis and mass spectrometry, Phytochemistry 67, 2431-2440.

[6] Matthews, D. E., Hessler, R. A., Denslow, N. D., Edwards, J. S., and O’Brien, T. W. (1982) Protein composition of the bovine mitochondrial ribosome, J Bio/ Chem 257, 8788-8794.

[7] Orvos, D. R., Sellers, C. M., Jr., and Garrison, N. E. (1987) Optimal isolation conditions for rainbow trout (Salmo gairdneri) hepatic ribosomes, Comparative biochemistry and physiology. B, Comparative biochemistry 88, 141-145.

[8] Warburg, O., Christian, W. (1942) Isolierung und kristallisation des garangsferementens enolase, Biochemical Z 374-421, 374-421.

[9] Layne, E. (1957) Spectrophotometric and turbidimetric methods for measuring proteins, Methods Enzymol. 3, 447-454.

\section{ABOUT THE STUDENT AUTHORS}

Yoshihiro Miura graduated from SUNY Oswego in December 2012 with a BS in Biochemistry and Biology. He chose to get his D.P.T. degree at Columbia University, NYC, New York.

Eric Yeager graduated from the State University of New York (SUNY) at Oswego in May, 2010 with a BS degree in Zoology (minor in Chemistry). He is currently living in Ithaca, NY, while attending the New York State College of Veterinary Medicine at Cornell University pursuing his Doctorate in Veterinary Medicine (DVM).

\section{PRESS SUMMARY}

Ribosomes are central to protein synthesis and our understanding of ribosomes has advanced antibiotics research. We purified ribosomes and then ribosomal proteins and identified some of those proteins in five species: bacteria, yeast, salmon, chicken, and cow. We taught these advanced techniques to a class of biochemistry students. We suggest that other biochemists could use our protocols for teaching ultracentrifugation and proteomics in their teaching laboratories. 